\title{
Milk fatty acid composition in Holstein x Gyr dairy cows fed chopped elephantgrass-based diets containing two types of sunflower oil associated with two methods of concentrate feeding
}

\section{Perfil de ácidos graxos do leite de vacas Holandês x Gir alimentadas com dietas à base de capim-elefante picado, dois tipos de óleo de girassol e dois modos de fornecimento do concentrado}

\author{
Fernando César Ferraz Lopes ${ }^{1 *}$; Carlos Gustavo Santos Ribeiro ${ }^{2}$; Norberto Mario \\ Rodriguez ${ }^{3}$; Marco Antônio Sundfeld da Gama ${ }^{4}$; Mirton José Frota Morenz ${ }^{4}$
}

\section{Highlights:}

TMR-fed cows consumed more dry matter than those fed with concentrate supplied twice a day. The method of concentrate feeding and sunflower oil type did not alter milk, fat and protein yields. Cows fed with concentrate supplied twice a day presented a higher milk fat rumenic acid content. The milk fat of high oleic sunflower oil-fed cows presented a higher oleic acid content.

The milk fat of medium oleic sunflower oil-fed cows presented a higher rumenic acid content.

\begin{abstract}
Two experiments were carried out in a $2 \times 2$ factorial arrangement with the objective of evaluating two methods of concentrate feeding for Holstein x Gyr cows fed $600 \mathrm{~g} \mathrm{~kg}^{-1}$ chopped elephantgrass-based diets supplemented at $45 \mathrm{~g} \mathrm{~kg}^{-1} \mathrm{DM}$ with two types of sunflower oil (SO). The types of $\mathrm{SO}$ differed in the

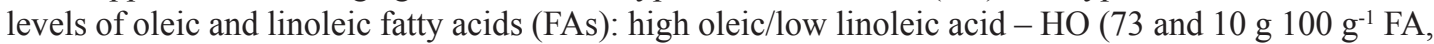

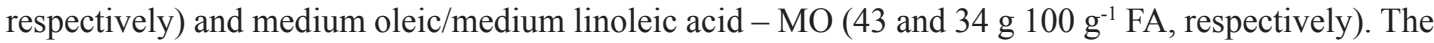
concentrates containing HO SO or MO SO were supplied separately from the forage twice a day after the two milkings (TAD) or as part of a total mixed ration (TMR). In Experiment 1, a 4 x 4 Latin square design was used to evaluate the ruminal fermentation and degradation parameters in four rumen-cannulated cows ( $430 \pm 39 \mathrm{~kg} ; 79 \pm 20$ days in milk; $16.4 \pm 3.1 \mathrm{~kg}^{\text {day }}{ }^{-1}$ of milk). In Experiment 2, a randomized block design was used to evaluate the nutrient intake, plasma contents of metabolites and FAs, milk yield and composition, and FA profile of milk fat in 32 cows $\left(444 \pm 84 \mathrm{~kg} ; 75 \pm 31\right.$ days in milk; $15.4 \pm 4.8 \mathrm{~kg}^{2}$ day $^{-1}$ of milk). The results were analyzed by mixed models $(\mathrm{P}<0.05)$. The TMR diets promoted higher nutrient intake and rumen fermentation (higher ammonia $\mathrm{N}$, acetate, propionate and total volatile FA contents) without affecting milk, fat, protein and lactose yields. TAD-fed cows presented higher feed efficiency and produced milk fat with a more nutritionally desirable FA composition, with higher vaccenic and rumenic acid contents and lower trans-10 C18:1 and palmitic acid contents. The DM intake, parameters of rumen fermentation and milk, fat, protein and lactose yields were similar for the HO SO and MO SO diets. The most nutritionally positive characteristics for human health in the milk fat of HO SO-fed
\end{abstract}

\footnotetext{
${ }^{1}$ Analista, Empresa Brasileira de Pesquisa Agropecuária, EMBRAPA Gado de Leite, Juiz de Fora, MG, Brasil. E-mail: fernando. lopes@embrapa.br

2 Prof., Instituto Federal de Educação, Ciência e Tecnologia, IFB, Campus Planaltina, Brasília, DF, Brasil. E-mail: carlos.ribeiro@ ifb.edu.br

${ }^{3}$ Prof., Departamento de Zootecnia, Escola de Veterinária, Universidade Federal de Minas Gerais, UFMG, Belo Horizonte, MG, Brasil. E-mail: norberto.bhe@terra.com.br

${ }^{4}$ Pesquisadores, EMBRAPA Gado de Leite, Juiz de Fora, MG, Brasil. E-mail: marco.gama@embrapa.br; mirton.morenz@ embrapa.br

* Author for correspondence
} 
cows were the higher eicosapentaenoic $(+34 \%)$ and oleic acid $(+11 \%)$ contents and lower palmitic acid content $(-10 \%)$. Higher contents of vaccenic $(+71 \%)$ and rumenic $(+74 \%)$ acids and lower trans-10 C18:1 (-10\%), elaidic (-32\%), lauric (-14\%) and myristic (-11\%) acid contents were the most positive aspects of the milk fat of MO SO-fed cows. Considering the magnitudes of the differences in the levels of these FAs, it is concluded that the milk fat of cows fed MO SO showed a healthier milk FA profile.

Key words: Conjugated linoleic acid. Oleic acid. Pennisetum purpureum. Rumenic acid. TMR.

\section{Resumo}

Dois experimentos foram realizados em esquema de arranjo fatorial 2 × 2, com o objetivo de avaliar dois métodos de fornecimento de concentrado para vacas Holandês x Gir recebendo dietas à base de $600 \mathrm{~g} \mathrm{~kg}^{-1}$ de capim-elefante picado, suplementadas com dois tipos de óleo de girassol (OG) na base de $45 \mathrm{~g} \mathrm{~kg}^{-1} \mathrm{da}^{-1}$ matéria seca (MS) da dieta. Os OG diferiram por apresentar teores contrastantes dos ácidos graxos (AG) oleico e linoleico: alto teor de ácido oleico/baixo teor de ácido linoleico - HO (respectivamente, $73 \mathrm{e}$

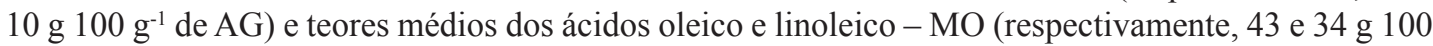
$\mathrm{g}^{-1}$ de AG). Os concentrados contendo os OG foram fornecidos separadamente da forragem, duas vezes ao dia, após as duas ordenhas (TAD), ou como parte de uma dieta completa (TMR). No experimento 1, utilizou-se delineamento quadrado latino 4 x 4 para avaliar a fermentação e degradação ruminal em quatro vacas canuladas no rúmen $\left(430 \pm 39 \mathrm{~kg}\right.$; $79 \pm 20$ dias em lactação; $16,4 \pm 3,1 \mathrm{~kg} \mathrm{dia}^{-1}$ de leite). No experimento 2, foi utilizado delineamento em blocos casualizados para avaliar o consumo de nutrientes, as concentrações plasmáticas de metabólitos e AG, e a produção, composição e o perfil de AG do leite em 32 vacas (444 $\pm 84 \mathrm{~kg} ; 75 \pm 31$ dias em lactação; $15,4 \pm 4,8 \mathrm{~kg} \mathrm{dia}^{-1}$ de leite). Os resultados foram analisados por modelos mistos $(\mathrm{P}<0,05)$. As dietas fornecidas como TMR promoveram maior ingestão de nutrientes e fermentação ruminal (maiores teores de $\mathrm{N}$ amoniacal, acetato, propionato e $\mathrm{AG}$ voláteis totais), mas sem efeito nas produções de leite, gordura, proteína e lactose. As vacas que receberam concentrado duas vezes ao dia apresentaram maior eficiência alimentar e produziram leite com perfil de AG mais saudável, com maiores teores dos ácidos vacênico e rumênico, e menores de C18:1 trans-10 e ácido palmítico. O tipo de $\mathrm{OG}$ não influenciou a ingestão de MS, a fermentação ruminal e as produções de leite, gordura, proteína e lactose. As características nutricionais mais positivas na gordura do leite das vacas que receberam OG HO foram os maiores teores dos ácidos eicosapentaenoico $(+34 \%)$ e oleico $(+11 \%)$ e o menor teor de ácido palmítico $(-10 \%)$. Maiores teores dos ácidos vacênico $(+71 \%)$ e rumênico (+74\%) e menores dos ácidos elaídico (-32\%), láurico (-14\%), mirístico (-11\%) e C18:1 trans-10 (-10\%) foram os aspectos nutricionais mais positivos na gordura do leite das vacas alimentadas com OG MO. Considerando as magnitudes das diferenças nos teores desses AG, conclui-se que a gordura do leite das vacas que receberam o OG MO apresentou perfil de AG mais saudável.

Palavras-chave: Ácido linoleico conjugado. Ácido oleico. Ácido rumênico. Pennisetum purpureum. TMR.

\section{Introduction}

Total mixed rations (TMRs) have been used for feeding cows since the 1950s. An advantage of feeding TMRs as opposed to feeding forages supplemented with concentrates is the opportunity to make every bite of feed essentially a complete, nutritionally balanced diet (Schingoethe, 2017). Another advantage related to TMR feeding is the opportunity to minimize digestive upset due to dramatic fluctuations in ruminal $\mathrm{pH}$ (Renna et al., 2014). A decreased rumen $\mathrm{pH}$ can alter the microbial population (e.g., cellulolytic bacteria) and, especially in diets rich in polyunsaturated fatty acids (PUFAs), can promote a shift from the normal trans-11 to the trans-10 alternative biohydrogenation $(\mathrm{BH})$ pathway of dietary linoleic acid (cis-9, cis-12 C18:2), promoting an increase in the rumen contents of trans-10 C18:1 and trans-10, cis-12 CLA (Rico, Preston, Risser, \& Harvatine, 2015). These rumen-derived bioactive fatty acids 
(FAs) and trans-9, cis-11 CLA are associated with the reduction in de novo FA synthesis in the mammary gland (Shingfield, Bernard, Leroux, \& Chilliard, 2010; Bernard et al., 2018), promoting milk fat depression (MFD). In studies conducted with medium-yielding cows $\left(\leq 20 \mathrm{~kg} \mathrm{day}^{-1}\right)$, the DM intake of TMR-fed cows was similar (Renna et al., 2014) or higher (Agnew, Mayne, \& Doherty, 1996) than those who received concentrate separately from forage. In these studies, there was no effect of the method of feeding concentrate on the milk yield; milk contents of fat, protein and lactose; or on overall milk FA composition.

In Brazil, elephantgrass (Pennisetum purpureum, Schumach) is one of the most important tropical grasses for feeding dairy cows in a cut-and-carry system (Pereira, Morenz, Ledo, \& Ferreira, 2016). Studies carried out by our research group have shown that the inclusion of up to $45 \mathrm{~g} \mathrm{~kg}^{-1}$ vegetable oils rich in linoleic acid (i.e., soybean or sunflower oil) in the DM of chopped elephantgrass-based TMRs improved the nutritional quality of milk (Ribeiro, Lopes, Gama, Morenz, \& Rodriguez, 2014; Ribeiro, Lopes, Gama, Rodriguez, \& Morenz, 2018; F. C. F. Lopes et al., 2019). Supplementation with these oils promoted an increase in the milk fat content of oleic (cis-9 C18:1), rumenic (cis9, trans-11 CLA) and vaccenic (trans-11 C18:1) acids, which are beneficial to human health, and a concomitant reduction in hypercholesterolemic lauric (C12:0), myristic (C14:0) and palmitic (C16:0) acids. However, in the studies by Ribeiro et al. (2018) and F. C. F. Lopes et al. (2019), there were linear increments $(\mathrm{P}<0.05)$ in the milk fat contents of trans-10 C18:1, trans-10, cis-12 CLA and trans-9, cis-11 CLA, which promoted MFD, indicated by the linear reduction $(\mathrm{P}<0.001)$ in milk fat content.

Feeding diets rich in linoleic acid resulted in a lower milk fat content (He, Perfield, Green, \& Armentano, 2012; J. C. Lopes et al., 2017) and yield (Weld \& Armentano, 2018) than those rich in oleic acid. Studies have shown that dietary linoleic acid is more potent than oleic acid at causing MFD because linoleic acid has a greater inhibitory effect on milk fat de novo-synthesized FA yields (He et al., 2012; Dorea \& Armentano, 2017). The rumen-derived FAs trans-10, cis-12 CLA and trans-9, cis-11 CLA are intermediates of ruminal linoleic acid $\mathrm{BH}$ reactions, whereas the oleic acid BH does not produce these CLA isomers (Shingfield et al., 2010; Buccioni, Decandia, Minieri, Molle, \& Cabiddu, 2012). On the other hand, trans-10 C18:1 originates both from linoleic acid $\mathrm{BH}$ and from the isomerization of oleic acid in the rumen (Shingfield et al., 2010). However, although trans-10 C18:1 has a higher efficiency of transfer from the abomasum into milk than trans-10, cis-12 CLA, its putative antilipogenic effect is 40- to 50-fold lower than that of CLA (Shingfield, Sæbø, Sæbø, Toivonen, \& Griinari, 2009). In addition, the magnitude of increased milk trans-10 C18:1 associated with dietary linoleic acid is twice that associated with dietary oleic acid (Stoffel, Crump, \& Armentano, 2015).

On the basis of the abovementioned considerations, the first objective of this study was to evaluate the effects of feeding concentrate twice a day separately from forage or as a TMR on the ruminal fermentation and degradation parameters, intake of nutrients, plasma concentrations of metabolites and FAs, and milk yield and composition, with particular emphasis on the FA composition of milk fat in Holstein x Gyr medium-producing dairy cows. The second objective of this study was to evaluate the effect of feeding cows with two types of SO differing in oleic and linoleic acid contents.

\section{Materials and Methods}

The study consisted of two experiments carried out at Embrapa Dairy Cattle (Coronel Pacheco, MG, Brazil) from February to April 2011. All of the experimental procedures with animals were conducted according to Embrapa Dairy Cattle guidelines for animal care and use in research. Both experiments were carried out in a $2 \times 2$ factorial 
arrangement and aimed to evaluate two types of sunflower oil (SO) associated with two methods of concentrate feeding in Holstein x Gyr cows. The two types of SO differed in the levels of oleic and linoleic acids (Table 1): high oleic/low linoleic acid SO (HO) and medium oleic/medium linoleic acid SO (MO). The two types of SO were mixed with other concentrate feeds (ground corn, soybean meal, citrus pulp, and mineral/vitamin supplement). The concentrates containing $\mathrm{HO} \mathrm{SO}$ or MO SO were supplied separately from the forage twice a day after the two milkings (TAD) or as part of a total mixed ration (TMR). Thus, the four treatments evaluated were HO-TAD, HO-TMR, MO-TAD, and MO-TMR.

\section{Table 1}

Fatty acid (FA) composition of the experimental diets and ingredients

\begin{tabular}{|c|c|c|c|c|c|c|c|c|}
\hline \multirow{2}{*}{$\begin{array}{l}\text { Fatty acid } \\
\left(\mathrm{g} 100 \mathrm{~g}^{-1} \mathrm{FA}\right)\end{array}$} & \multicolumn{2}{|c|}{ Diet } & \multirow{2}{*}{$\begin{array}{c}\text { Chopped } \\
\text { elephantgrass }\end{array}$} & \multirow{2}{*}{$\begin{array}{c}\text { Soybean } \\
\text { meal }\end{array}$} & \multirow{2}{*}{$\begin{array}{l}\text { Ground } \\
\text { corn }\end{array}$} & \multirow{2}{*}{$\begin{array}{l}\text { Citrus } \\
\text { pulp }\end{array}$} & \multicolumn{2}{|c|}{ Sunflower oil ${ }^{\mathrm{b}}$} \\
\hline & $\begin{array}{l}\text { High } \\
\text { oleic }\end{array}$ & $\begin{array}{c}\text { Medium } \\
\text { oleic }\end{array}$ & & & & & $\begin{array}{l}\text { High } \\
\text { oleic }\end{array}$ & $\begin{array}{c}\text { Medium } \\
\text { oleic }\end{array}$ \\
\hline Palmitic acid & 14.01 & 15.13 & $19.23 \pm 1.71$ & 19.67 & 16.50 & 22.93 & 5.9 & 10.5 \\
\hline Stearic acid & 19.19 & 20.02 & $2.17 \pm 0.38$ & 4.12 & 2.56 & 4.02 & 3.1 & 3.4 \\
\hline Oleic acid & 21.26 & 14.37 & $4.82 \pm 1.05$ & 15.21 & 29.11 & 19.30 & 72.7 & 42.7 \\
\hline Linoleic acid & 14.26 & 19.83 & $14.96 \pm 1.04$ & 46.97 & 42.87 & 28.95 & 10.4 & 33.6 \\
\hline$\alpha$-linolenic acid & 16.27 & 16.77 & $26.58 \pm 2.04$ & 4.08 & 1.09 & 4.16 & 0.4 & 2.6 \\
\hline
\end{tabular}

${ }^{\mathrm{a}}$ Mean \pm standard deviation ( $n=3$ samples); ${ }^{\text {}}$ Triângulo Alimentos Ltda. (Itápolis, SP, Brazil).

The diets were formulated (DM basis) with 600 $\mathrm{g} \mathrm{kg}^{-1}$ chopped elephantgrass, $80 \mathrm{~g} \mathrm{~kg}^{-1}$ ground corn, $180 \mathrm{~g} \mathrm{~kg}^{-1}$ soybean meal, $80 \mathrm{~g} \mathrm{~kg}^{-1}$ citrus pulp, 45 $\mathrm{g} \mathrm{kg}^{-1} \mathrm{SO}$ (Triângulo Alimentos Ltda., Itápolis, SP, Brazil), and $15 \mathrm{~g} \mathrm{~kg}^{-1}$ mineral/vitamin supplement (Top Milk Núcleo ${ }^{\circledR}$; Matsuda, Álvares Machado, SP, Brazil). The Napier cultivar of elephantgrass was used (70 to 90 days of growth), which was cut every two days and chopped daily (Table 2 ). The concentrates were prepared weekly to avoid lipid peroxidation, and they were formulated with the following (DM basis): $199 \mathrm{~g} \mathrm{~kg}^{-1}$ ground corn, 450 $\mathrm{g} \mathrm{kg}^{-1}$ soybean meal, $199 \mathrm{~g} \mathrm{~kg}^{-1}$ citrus pulp, $111 \mathrm{~g}$ $\mathrm{kg}^{-1} \mathrm{SO}$ and $41 \mathrm{~g} \mathrm{~kg}^{-1}$ mineral/vitamin supplement. The chemical compositions of elephantgrass and the concentrates are shown in Table 2, while the FA compositions of the HO SO and MO SO diets and ingredients of the diets are shown in Table 1.

\section{Table 2}

\section{Chemical composition of the chopped elephantgrass and experimental concentrates}

\begin{tabular}{lccc}
\hline \multirow{2}{*}{$\begin{array}{l}\text { Chemical composition } \\
\left.\mathrm{g} \mathrm{kg}^{-1} \text { dry matter}\right)\end{array}$} & Chopped elephantgrass & \multicolumn{2}{c}{ Concentrates } \\
\cline { 3 - 4 } Dry matter, $\mathrm{g} \mathrm{kg}^{-1}$ as fed & $258 \pm 22$ & High oleic & Medium oleic \\
\hline Crude protein & $64 \pm 1$ & 234 & 884 \\
Ether extract & $24 \pm 7$ & 135 & 255 \\
Neutral detergent fiber corrected for ash and protein & $719 \pm 35$ & 156 & 130 \\
Lignin & $75 \pm 3$ & 22 & 146 \\
In vitro dry matter digestibility $\left(\mathrm{g} \mathrm{kg}^{-1}\right)$ & $482 \pm 5$ & 784 & 24 \\
\hline
\end{tabular}

${ }^{a}$ Mean \pm standard deviation $(n=3$ samples). 
The cows were collectively lodged in a free stall with available water and mineral mix. The diets were supplied ad libitum (10\% of orts) in troughs equipped with electronic gates (American Calan Inc., Northwood, NH, USA) for individual control of feed intake. For TMR diets, the roughage and concentrate were weighed, mixed and distributed individually in the troughs once a day after the morning milking using a mixer/dispenser vehicle (Calan Super Data Ranger; American Calan Inc.). In TAD diets, the daily amount of concentrates was divided equally and supplied separately from the forage twice a day after the morning and afternoon milkings. In the morning, the concentrate was supplied in the trough, and after its consumption, the forage was placed in the trough. In the afternoon, before supplying the concentrate, the forage that was in the trough was removed, and after the cow consumed all the concentrate, the forage was returned to the trough.

In Experiment 1, the ruminal fermentation and degradation parameters were evaluated in four rumen-cannulated cows $(430 \pm 39 \mathrm{~kg} ; 79 \pm 20$ days in milk; $16.4 \pm 3.1 \mathrm{~kg} \mathrm{day}^{-1}$ of milk). A 4 x 4 Latin square (LS) experimental design with 15-day periods was used, with the first 10 days for diet adaptation and the remaining five days for sampling and data recording. Throughout the experiment, the average DM intake of cows was 3.36, 3.63, 2.83 and 2.86 $\mathrm{kg} 100 \mathrm{~kg}^{-1}$ of body weight, and the average milk yields were 17.6, 17.2, 16.0 and $15.6 \mathrm{~kg} \mathrm{day}^{-1}$ for the HO-TMR, MO-TMR, HO-TAD and MO-TAD treatments, respectively.

The ruminal parameters were evaluated on the $11^{\text {th }}$ and $12^{\text {th }}$ days of each LS period. Samples of ruminal fluid were collected before (time 0 ) and 4, 6, 8, 10, 12,16 hours ( $11^{\text {th }}$ day) and 24 hours ( $12^{\text {th }}$ day) after the provision of the morning rations. Ruminal fluid sample collection procedures for $\mathrm{pH}$ determination and for analysis of the rumen ammonia $\mathrm{N}$ content $\left(\mathrm{N}-\mathrm{NH}_{3}\right)$ and molar concentration $\left(\mathrm{mMol} 100 \mathrm{~mL}^{-1}\right)$ of volatile fatty acids (VFAs) have been described in detail by Ribeiro et al. (2018).
For the study of ruminal degradability, a predried $\left(55^{\circ} \mathrm{C}, 72 \mathrm{~h}\right)$ and milled $(5 \mathrm{~mm})$ sample of chopped elephantgrass was used, which was conditioned in nylon bags $(10 \times 20 \mathrm{~cm}, 50 \mu$ porosity, $10-20 \mathrm{mg}$ of sample per $\mathrm{cm}^{2}$ ) incubated in the rumen of each cow in each LS period. The procedures for removal of nylon bags from the rumen, processing and chemical analysis of incubation residues and the estimation of ruminal degradability parameters have been described in detail by Mourthé et al. (2019).

In Experiment 2, the nutrient intake, plasma contents of metabolites and FAs, milk yield and composition, and FA profile of milk fat were evaluated in 32 primiparous cows $(444 \pm 84 \mathrm{~kg})$ with $75 \pm 31$ days in milk and producing $15.4 \pm 4.8$ $\mathrm{kg} \mathrm{day}^{-1}$ of milk at the beginning of the study. The experimental design was a randomized block lasting 21 days, with the first 14 days for diet adaptation and the remaining seven days for sampling and data recording. The cows were homogeneously distributed in the blocks based on milk yield, days in milk, body weight and genetic composition (varying from 1/2 to 15/16 Holstein x Gyr).

From the $15^{\text {th }}$ to $21^{\text {st }}$ day of the experimental period, the voluntary intake of each cow was measured as the difference between the daily quantity of feed that was supplied and its respective ort. During this period, samples of chopped elephantgrass and the HO SO and MO SO concentrates were collected (Table 2). Samples of individual orts were also collected and pooled per cow. All those samples were stored $\left(-20^{\circ} \mathrm{C}\right)$, subsequently thawed, predried $\left(55^{\circ} \mathrm{C}, 72-96 \mathrm{~h}\right)$, milled $(1 \mathrm{~mm})$ and analyzed in the Laboratory of Food Analysis of Embrapa Dairy Cattle (Juiz de Fora, MG, Brazil) for DM (at $105^{\circ} \mathrm{C}$ ), crude protein $(\mathrm{CP})$, ether extract $(\mathrm{EE})$, mineral matter, NDF corrected for ash and protein $\left(\mathrm{NDF}_{\mathrm{ap}}\right)$ and lignin content, according to Detmann et al. (2012).

Samples of chopped elephantgrass and each ingredient of the concentrates in addition to the SO (HO and MO) were also collected from the $15^{\text {th }}$ 
to $21^{\text {st }}$ day of the experimental period. A portion of HO SO and MO SO concentrates prepared the day before the beginning of the experiment was sampled (day 1), and the rest were stored. Aliquots were collected on the $7^{\text {th }}, 14^{\text {th }}, 21^{\text {st }}, 28^{\text {th }}$ and $35^{\text {th }}$ days after their preparation to evaluate possible changes in their FA profile due to lipid peroxidation
(Table 3). All of these samples were frozen, subsequently lyophilized, ground and analyzed for FA composition by gas chromatography (GC) at the Laboratory of Chromatography of Embrapa Dairy Cattle (Juiz de Fora, MG). The sample digestion, methylation and analysis procedures were described by F. C. F. Lopes et al. (2019).

Table 3

Fatty acid (FA) composition of concentrates as a function of days elapsed since their preparation

\begin{tabular}{|c|c|c|c|c|c|c|c|c|c|c|c|c|}
\hline \multirow{3}{*}{$\begin{array}{l}\text { Fatty acid } \\
\left(\mathrm{g} 100 \mathrm{~g}^{-1} \mathrm{FA}\right)\end{array}$} & \multicolumn{6}{|c|}{ High oleic } & \multicolumn{6}{|c|}{ Medium oleic } \\
\hline & \multicolumn{12}{|c|}{ Days elapsed since concentrate preparation } \\
\hline & 1 & 7 & 14 & 21 & 28 & 35 & 1 & 7 & 14 & 21 & 28 & 35 \\
\hline Palmitic acid & 8.4 & 8.3 & 8.3 & 8.3 & 8.3 & 8.5 & 12.0 & 12.0 & 12.1 & 11.8 & 12.2 & 12.1 \\
\hline Stearic acid & 3.0 & 3.0 & 3.0 & 2.9 & 2.9 & 3.0 & 3.1 & 3.2 & 3.3 & 3.2 & 3.2 & 3.2 \\
\hline Oleic acid & 61.2 & 61.0 & 61.6 & 60.5 & 61.3 & 60.9 & 38.2 & 39.0 & 37.9 & 38.9 & 39.3 & 39.0 \\
\hline Linoleic acid & 17.6 & 17.8 & 17.6 & 18.1 & 17.9 & 17.8 & 36.2 & 35.9 & 35.6 & 35.8 & 35.3 & 35.6 \\
\hline$\alpha$-linolenic acid & 1.1 & 1.1 & 1.0 & 1.1 & 1.0 & 1.0 & 2.7 & 2.8 & 2.7 & 2.5 & 2.5 & 2.5 \\
\hline
\end{tabular}

Cows were milked twice daily $(06 \mathrm{~h} 00$ and 14h00), and milk yields were recorded from the $15^{\text {th }}$ to $21^{\text {st }}$ day of the experiment. During this period, two replicate milk samples $(50 \mathrm{~mL})$ were collected ( $2 / 3$ at morning milking $+1 / 3$ at afternoon milking). The first samples were stored in bottles with a bronopol preservative and analyzed for protein, fat and lactose milk contents by medium infrared spectrometry (Bentley 2300; Bentley Instruments, Inc., Chaska, MN, USA) at the Milk Quality Laboratory of Embrapa Dairy Cattle (Juiz de Fora, MG). The second samples were stored in bottles without preservative, frozen, subsequently thawed, and analyzed by GC at the Laboratory of Chromatography of Embrapa Dairy Cattle, according to the procedures described by Mourthé et al. (2019).

Blood samples were collected on the $21^{\text {st }}$ day of the experimental period via coccygeal venipuncture using test tubes (Vacutainer; BectonDickinson, Rutherford, NJ, USA) containing EDTA anticoagulant. The samples were immediately centrifuged at $1,500 \times \mathrm{g}$ for $15 \mathrm{~min}$, and plasma $(2 \mathrm{~mL})$ was stored in tubes $\left(-20^{\circ} \mathrm{C}\right)$ until analysis. The plasma contents of nonesterified FA (NEFA), glucose, and urea nitrogen were analyzed using commercial kits as described by Rodrigues et al. (2017), and FA composition was analyzed by GC according to the one-step transmethylation procedure proposed by Masood, Stark and Salem (2005).

The results were analyzed by mixed models using the MIXED procedure of SAS. The ruminal fermentation parameters (Experiment 1) were analyzed as repeated measures in time and were considered to be fixed effects: LS period, method of concentrate feeding $(\mathrm{M})$, type of SO $(\mathrm{O})$, sampling time $(\mathrm{T})$, and the interactions $\mathrm{M}^{*} \mathrm{O}, \mathrm{M}^{*} \mathrm{~T}, \mathrm{O}^{*} \mathrm{~T}$ and $\mathrm{M}^{*} \mathrm{O} * \mathrm{~T}$. Cow* ${ }^{*} \mathrm{O}$ and $\mathrm{O}$ were considered random effects. Ten matrices of covariance were evaluated based on the Akaike information criterion. The DM and NDF degradability parameters of elephantgrass forage (Experiment 1) were analyzed considering the fixed effects LS period, M, O and the interaction 
$\mathrm{M}^{*} \mathrm{O}$, and cow as a random effect. The variables concerning Experiment 2 were analyzed considering the fixed effects $\mathrm{M}, \mathrm{O}$ and the interaction between these factors, and the random effect cow*M. The results are reported as least squares means, and significant differences were declared at $\mathrm{P}<0.05$.

\section{Results}

In general, changes in the FA composition in both concentrates were minimal over 35 days after their preparation (Table 3), demonstrating that during this storage period, there is no damage to their lipid composition due to peroxidation of unsaturated FAs.

There was no effect $(\mathrm{P}>0.05)$ of oil type on ruminal parameters (Table 4). There was an effect $(\mathrm{P}<0.05)$ of the method of concentrate feeding; lower rumen $\mathrm{pH}$ values and higher $\mathrm{N}_{-} \mathrm{NH}_{3}$, acetate, propionate and VFA rumen contents were observed in TMR-fed cows $(\mathrm{P}<0.05)$. There was no effect $(\mathrm{P}>0.05)$ of the method of concentrate feeding or oil type on the DM and NDF degradability parameters of elephantgrass (Table 4).

Table 4

Ruminal fermentation parameters and the dry matter (DM) and neutral detergent fiber (NDF) degradability parameters of elephantgrass in cows fed chopped elephantgrass-based diets containing two types of sunflower oil (high versus medium oleic acid content) associated with two methods of concentrate feeding (TMR versus twice a day after the morning and afternoon milkings)

\begin{tabular}{|c|c|c|c|c|c|c|c|c|}
\hline \multirow[b]{2}{*}{ Item } & \multicolumn{2}{|c|}{ TMR } & \multicolumn{2}{|c|}{ Twice a day } & \multirow[b]{2}{*}{ SEM } & \multicolumn{3}{|c|}{ P-value } \\
\hline & $\begin{array}{l}\text { High } \\
\text { oleic }\end{array}$ & $\begin{array}{l}\text { Medium } \\
\text { oleic }\end{array}$ & $\begin{array}{l}\text { High } \\
\text { oleic }\end{array}$ & $\begin{array}{c}\text { Medium } \\
\text { oleic }\end{array}$ & & $\begin{array}{l}\text { Method } \\
\text { (M) }\end{array}$ & $\begin{array}{l}\text { Oil } \\
(\mathrm{O})\end{array}$ & $\mathrm{M}^{*} \mathrm{O}$ \\
\hline \multicolumn{9}{|c|}{ Ruminal fermentation parameter } \\
\hline $\mathrm{pH}$ & 6.28 & 6.38 & 6.48 & 6.48 & 0.0543 & 0.0239 & 0.3503 & 0.3670 \\
\hline Ammonia $\mathrm{N}, \mathrm{mg} \mathrm{dL}^{-1}$ & 17.35 & 15.70 & 14.87 & 13.18 & 0.8259 & 0.0145 & 0.0684 & 0.8546 \\
\hline Acetate & 61.04 & 56.40 & 50.71 & 50.95 & 1.7270 & 0.0013 & 0.2344 & 0.1916 \\
\hline Propionate & 18.01 & 17.74 & 15.32 & 15.12 & 0.4874 & 0.0004 & 0.6369 & 0.9489 \\
\hline Butyrate & 8.93 & 8.53 & 8.01 & 8.20 & 0.3400 & 0.0996 & 0.7580 & 0.4089 \\
\hline $\mathrm{VFA}^{\mathrm{a}}$ & 87.91 & 82.31 & 74.10 & 74.33 & 2.2347 & 0.0009 & 0.2601 & 0.2245 \\
\hline \multicolumn{9}{|c|}{ Ruminal DM degradability } \\
\hline $\mathrm{PD}, \%$ & 55.0 & 56.4 & 56.6 & 56.0 & 0.8417 & 0.4381 & 0.6003 & 0.1929 \\
\hline $\mathrm{k}, \%$ hour $^{-1}$ & 3.96 & 3.46 & 3.16 & 4.03 & 0.6551 & 0.8707 & 0.7885 & 0.3385 \\
\hline $\mathrm{ED}, \%$ & 35.3 & 34.6 & 33.4 & 36.4 & 2.0037 & 0.9663 & 0.5734 & 0.3829 \\
\hline \multicolumn{9}{|c|}{ Ruminal NDF degradability ${ }^{b}$} \\
\hline $\mathrm{PD}, \%$ & 54.9 & 53.5 & 51.0 & 51.0 & 1.5478 & 0.0729 & 0.6351 & 0.6284 \\
\hline $\mathrm{k}, \%$ hour $^{-1}$ & 3.34 & 2.64 & 3.57 & 3.54 & 0.3827 & 0.1870 & 0.3801 & 0.4184 \\
\hline ED, \% & 21.1 & 17.7 & 21.8 & 21.2 & 1.0287 & 0.0890 & 0.1055 & 0.2285 \\
\hline
\end{tabular}

${ }^{\mathrm{a}}$ VFA (volatile fatty acids $)=\Sigma$ rumen contents $\left(\mathrm{mMol} 100 \mathrm{~mL}^{-1}\right)$ of acetate + propionate + butyrate; ${ }^{\text {PD }}=$ potential degradability, $\mathrm{k}=$ degradation rate, and $\mathrm{ED}=$ effective degradability calculated considering the passage rate of solids in the rumen estimated by the National Research Council [NRC] (2001) equation.

There was an effect of the method of concentrate feeding $(\mathrm{P}=0.0008)$ and oil type $(\mathrm{P}=0.0123)$ on the rate passage of solids in the rumen; higher values were observed in TMR-fed cows and those receiving $\mathrm{HO} \mathrm{SO}$ (Table 5). There was an effect $(\mathrm{P}<0.05)$ of the method of concentrate feeding on 
nutrient intake; higher intakes of $\mathrm{DM}$ and $\mathrm{NDF}_{\text {ap }}$ (expressed in $\mathrm{kg}$ day-1 or $\mathrm{kg} 100 \mathrm{~kg}^{-1}$ body weight), $\mathrm{CP}$, nonfibrous carbohydrate corrected for ash and protein $\left(\mathrm{NFC}_{\mathrm{ap}}\right)$ and oleic, linoleic and $\alpha$-linolenic acids were observed in TMR-fed cows. The $\mathrm{M}^{*} \mathrm{O}$ interaction was significant $(\mathrm{P}=0.0398)$ only for $\mathrm{EE}$ intake (Table 5); a higher EE intake was observed for the cows receiving MO-TMR treatment than those fed with MO-TAD treatment. The DM and $\mathrm{NDF}_{\text {ap }}$

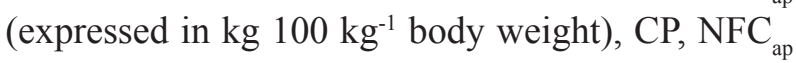
and oleic acid intakes were higher for $\mathrm{HO} \mathrm{SO}-\mathrm{fed}$ cows, while the MO-SO-fed cows consumed more linoleic and $\alpha$-linolenic acids (Table 5).

There was no effect $(\mathrm{P}>0.05)$ of the method of concentrate feeding or oil type on milk yield, fat- corrected milk (FCM) yield, and fat, protein, lactose and total solids yields (Table 6). There was also no effect $(\mathrm{P}>0.05)$ of the factors studied on fat, protein and total solids milk contents. The $\mathrm{M}^{*} \mathrm{O}$ interaction was significant $(\mathrm{P}=0.0128)$ only for milk lactose content (Table 6); in the MO SO diets, the cows receiving concentrate twice a day produced milk with a higher lactose content than those fed with TMR diets (Table 6). There was no effect $(\mathrm{P}>0.05)$ of oil type on feed efficiency ( $\mathrm{kg}$ of milk or FCM per $\mathrm{kg}$ of $\mathrm{DM}$ ), but TAD-fed cows presented a higher $(\mathrm{P} \leq 0.0001)$ feed efficiency than TMR-fed cows (Table 6).

Table 5

Rate passage of solids in the rumen (RP) and nutrient intake in cows fed chopped elephantgrass-based diets containing two types of sunflower oil (high versus medium oleic acid content) associated with two methods of concentrate feeding (TMR versus twice a day after the morning and afternoon milkings)

\begin{tabular}{|c|c|c|c|c|c|c|c|c|}
\hline \multirow[b]{2}{*}{ Item } & \multicolumn{2}{|c|}{ TMR } & \multicolumn{2}{|c|}{ Twice a day } & \multirow[b]{2}{*}{ SEM } & \multicolumn{3}{|c|}{ P-value } \\
\hline & $\begin{array}{l}\text { High } \\
\text { oleic }\end{array}$ & $\begin{array}{c}\text { Medium } \\
\text { oleic }\end{array}$ & $\begin{array}{l}\text { High } \\
\text { oleic }\end{array}$ & $\begin{array}{l}\text { Medium } \\
\text { oleic }\end{array}$ & & $\begin{array}{c}\text { Method } \\
\text { (M) }\end{array}$ & $\begin{array}{l}\text { Oil } \\
(\mathrm{O})\end{array}$ & $\mathrm{M} * \mathrm{O}$ \\
\hline $\operatorname{RP}\left(\% \text { hour }^{-1}\right)^{\mathrm{a}}$ & 5.41 & 5.16 & 5.07 & 4.87 & 0.0900 & 0.0008 & 0.0123 & 0.7512 \\
\hline \multicolumn{9}{|c|}{ Nutrient intake $\left(\mathrm{kg} \mathrm{day}^{-1}\right)$} \\
\hline Dry matter $(\mathrm{DM})$ & 14.0 & 14.1 & 13.1 & 11.9 & 0.3373 & $<0.0001$ & 0.1238 & 0.0566 \\
\hline Crude protein & 1.97 & 1.95 & 1.84 & 1.65 & 0.0472 & $<0.0001$ & 0.0248 & 0.0628 \\
\hline Ether extract ${ }^{\mathrm{b}}$ & $1.03 \mathrm{Ba}$ & $1.12 \mathrm{Aa}$ & $0.96 \mathrm{Aa}$ & $0.94 \mathrm{Ab}$ & 0.0257 & $<0.0001$ & 0.2626 & 0.0398 \\
\hline $\mathrm{NDF}_{\mathrm{ap}}^{\mathrm{c}}$ & 6.49 & 6.63 & 6.05 & 5.59 & 0.1572 & $<0.0001$ & 0.2890 & 0.0530 \\
\hline $\mathrm{NFC}_{\text {ap }}{ }^{\mathrm{d}}$ & 3.27 & 3.16 & 3.05 & 2.66 & 0.0773 & $<0.0001$ & 0.0021 & 0.0708 \\
\hline \multicolumn{9}{|c|}{ Fatty acid intake $\left(\mathrm{g} \mathrm{day}^{-1}\right)$} \\
\hline Palmitic acid & 59.5 & 77.0 & 55.3 & 66.7 & 1.7357 & 0.0001 & $<0.0001$ & 0.0771 \\
\hline Stearic acid & 17.6 & 19.0 & 16.4 & 16.4 & 0.4606 & 0.0001 & 0.1187 & 0.1559 \\
\hline Oleic acid & 335.3 & 209.4 & 311.1 & 181.3 & 6.9765 & 0.0002 & $<0.0001$ & 0.1617 \\
\hline Linoleic acid & 112.3 & 206.3 & 104.3 & 178.7 & 4.2087 & 0.0001 & $<0.0001$ & 0.0566 \\
\hline$\alpha$-linolenic acid & 25.0 & 33.8 & 23.3 & 29.3 & 0.7478 & 0.0003 & $<0.0001$ & 0.1391 \\
\hline \multicolumn{9}{|c|}{$\mathrm{DM}$ and $\mathrm{NDF}_{\mathrm{ap}}$ intake (kg $100 \mathrm{~kg}^{-1}$ of body weight) } \\
\hline $\mathrm{DM}$ & 3.84 & 3.43 & 3.28 & 2.96 & 0.1466 & 0.0008 & 0.0123 & 0.7512 \\
\hline $\mathrm{NDF}_{\mathrm{ap}}$ & 1.78 & 1.61 & 1.52 & 1.39 & 0.0686 & 0.0009 & 0.0249 & 0.7450 \\
\hline
\end{tabular}

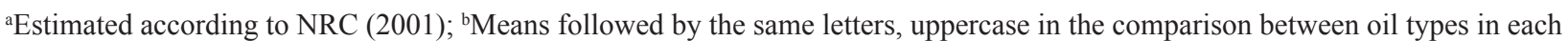
method of concentrate feeding and lowercase in the comparison between the methods of concentrate feeding for each oil type,

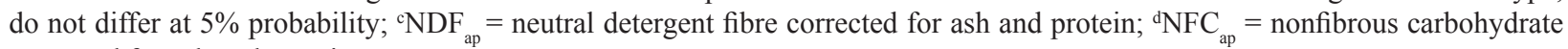
corrected for ash and protein. 
Table 6

Milk yield and composition of cows fed chopped elephantgrass-based diets containing two types of sunflower oil (high versus medium oleic acid content) associated with two methods of concentrate feeding (TMR versus twice a day after the morning and afternoon milkings)

\begin{tabular}{|c|c|c|c|c|c|c|c|c|}
\hline \multirow[b]{2}{*}{ Item } & \multicolumn{2}{|c|}{ TMR } & \multicolumn{2}{|c|}{ Twice a day } & \multirow[b]{2}{*}{ SEM } & \multicolumn{3}{|c|}{ P-value } \\
\hline & $\begin{array}{l}\text { High } \\
\text { oleic }\end{array}$ & $\begin{array}{c}\text { Medium } \\
\text { oleic }\end{array}$ & $\begin{array}{l}\text { High } \\
\text { oleic }\end{array}$ & $\begin{array}{c}\text { Medium } \\
\text { oleic }\end{array}$ & & $\begin{array}{l}\text { Method } \\
\text { (M) }\end{array}$ & $\begin{array}{l}\text { Oil } \\
(\mathrm{O}) \\
\end{array}$ & $\mathrm{M}^{*} \mathrm{O}$ \\
\hline \multicolumn{9}{|l|}{ Yield } \\
\hline Milk $\left(\mathrm{kg} \mathrm{day}^{-1}\right)$ & 13.2 & 12.8 & 14.4 & 13.9 & 0.7890 & 0.1496 & 0.5511 & 0.9502 \\
\hline FCM $\left(\mathrm{kg} \text { day }^{-1}\right)^{\mathrm{a}}$ & 12.1 & 11.9 & 13.4 & 13.2 & 0.7125 & 0.0670 & 0.7700 & 0.9563 \\
\hline Fat $\left(\mathrm{g} \mathrm{day}^{-1}\right)$ & 454.2 & 449.2 & 505.7 & 507.3 & 28.8578 & 0.0549 & 0.9500 & 0.9052 \\
\hline Protein $\left(\mathrm{g} \mathrm{day}^{-1}\right)$ & 366.6 & 362.9 & 405.0 & 378.9 & 21.2276 & 0.1281 & 0.6273 & 0.5124 \\
\hline Lactose $\left(\mathrm{g} \mathrm{day}^{-1}\right)$ & 575.6 & 543.0 & 618.2 & 622.2 & 36.6579 & 0.0584 & 0.8445 & 0.6582 \\
\hline Solids $\left(\mathrm{g} \mathrm{day}^{-1}\right)$ & $1,396.5$ & $1,355.0$ & $1,528.9$ & $1,508.3$ & 77.9703 & 0.0635 & 0.6793 & 0.8888 \\
\hline \multicolumn{9}{|l|}{ Composition (\%) } \\
\hline Fat & 3.49 & 3.51 & 3.56 & 3.65 & 0.1371 & 0.4200 & 0.6809 & 0.7711 \\
\hline Protein & 2.78 & 2.84 & 2.88 & 2.74 & 0.0605 & 0.9448 & 0.4630 & 0.1098 \\
\hline Lactose $^{\mathrm{b}}$ & $4.35 \mathrm{Aa}$ & $4.24 \mathrm{Ab}$ & $4.36 \mathrm{Aa}$ & $4.48 \mathrm{Aa}$ & 0.0453 & 0.0074 & 0.9803 & 0.0128 \\
\hline Total solids & 10.63 & 10.58 & 10.80 & 10.87 & 0.1705 & 0.1731 & 0.9265 & 0.7146 \\
\hline \multicolumn{9}{|l|}{ Feed efficiency } \\
\hline Milk $^{\mathrm{c}}$ & 0.94 & 0.91 & 1.10 & 1.17 & 0.0504 & 0.0001 & 0.7171 & 0.3026 \\
\hline $\mathrm{FCM}^{\mathrm{d}}$ & 0.86 & 0.84 & 1.02 & 1.11 & 0.0442 & $<0.0001$ & 0.4508 & 0.2002 \\
\hline
\end{tabular}

${ }^{a}$ Fat-corrected milk (NRC, 2001); ${ }^{b}$ Means followed by the same letters, uppercase in the comparison between oil types in each method of concentrate feeding and lowercase in the comparison between the methods of concentrate feeding for each oil type, do not differ at $5 \%$ probability; ${ }^{\mathrm{c} g}$ of milk/ $\mathrm{kg}$ of dry matter intake; ${ }^{\mathrm{d}} \mathrm{kg}$ of $\mathrm{FCM} / \mathrm{kg}$ of dry matter intake.

There was no effect $(\mathrm{P}>0.05)$ of the factors on plasma glucose, NEFA and urea $\mathrm{N}$ concentrations. There was an effect $(\mathrm{P}>0.05)$ of the method of concentrate feeding on the plasma contents of oddand branched-chain FA (OBCFA) anteiso C15:0, C15:0 and C17:0, with the highest levels being observed in TMR-fed cows (Table 7). Concerning the oil type, higher plasma contents of trans-10 $\mathrm{C} 18: 1$ and rumenic acid $(\mathrm{P}<0.01)$ were observed in cows receiving MO SO diets, while higher plasma contents of oleic acid and trans-10, cis-12 CLA $(\mathrm{P}<0.05)$ were observed in cows receiving HO SO diets (Table 7). The $\mathrm{M}^{*} \mathrm{O}$ interaction was significant $(\mathrm{P}<0.0001)$ for the plasma contents of vaccenic and linoleic acids; the higher levels of these FAs were observed in MO SO-fed cows, and considering the MO SO diets, higher plasma contents were observed in TAD-fed cows (Table 7). 
Table 7

Plasma concentrations of metabolites and major fatty acids in cows fed chopped elephantgrass-based diets containing two types of sunflower oil (high versus medium oleic acid content) associated with two methods of concentrate feeding (TMR versus twice a day after the morning and afternoon milkings)

\begin{tabular}{|c|c|c|c|c|c|c|c|c|}
\hline \multirow[b]{2}{*}{ Item } & \multicolumn{2}{|c|}{ TMR } & \multicolumn{2}{|c|}{ Twice a day } & \multirow[b]{2}{*}{ SEM } & \multicolumn{3}{|c|}{ P-value } \\
\hline & $\begin{array}{l}\text { High } \\
\text { oleic }\end{array}$ & $\begin{array}{l}\text { Medium } \\
\text { oleic }\end{array}$ & $\begin{array}{l}\text { High } \\
\text { oleic }\end{array}$ & $\begin{array}{l}\text { Medium } \\
\text { oleic }\end{array}$ & & $\begin{array}{l}\text { Method } \\
\text { (M) }\end{array}$ & $\begin{array}{l}\text { Oil } \\
(\mathrm{O})\end{array}$ & $\mathrm{M}^{*} \mathrm{O}$ \\
\hline \multicolumn{9}{|l|}{ Metabolites } \\
\hline Glucose $\left(\mathrm{mg} \mathrm{dL}^{-1}\right)$ & 57.6 & 56.8 & 55.7 & 55.0 & 1.1301 & 0.1016 & 0.4758 & 0.9898 \\
\hline NEFA $\left(\mathrm{mmol} \mathrm{L}^{-1}\right)^{\mathrm{a}}$ & 0.167 & 0.170 & 0.200 & 0.187 & 0.0258 & 0.3229 & 0.8922 & 0.7736 \\
\hline Urea $\mathrm{N}\left(\mathrm{mg} \mathrm{dL}^{-1}\right)$ & 45.0 & 42.5 & 48.0 & 44.5 & 1.9695 & 0.1920 & 0.1139 & 0.7880 \\
\hline \multicolumn{9}{|c|}{ Fatty acids - FA (g $\left.100 \mathrm{~g}^{-1} \mathrm{FA}\right)$} \\
\hline C12:0 & 0.070 & 0.062 & 0.070 & 0.061 & 0.0057 & 0.9041 & 0.1347 & 0.8868 \\
\hline $\mathrm{C} 14: 0$ & 0.67 & 0.64 & 0.67 & 0.61 & 0.0324 & 0.5264 & 0.1938 & 0.6741 \\
\hline $\mathrm{C} 16: 0$ & 11.16 & 11.46 & 11.66 & 11.25 & 0.3022 & 0.6273 & 0.8583 & 0.2530 \\
\hline C18:0 & 25.44 & 25.25 & 26.37 & 22.81 & 1.0646 & 0.4823 & 0.0869 & 0.1235 \\
\hline trans-9 C18:1 & 0.51 & 0.39 & 0.41 & 0.38 & 0.0396 & 0.1664 & 0.0637 & 0.2930 \\
\hline trans-10 C18:1 & 0.27 & 0.32 & 0.20 & 0.33 & 0.0269 & 0.2886 & 0.0026 & 0.1928 \\
\hline trans-11 C18: $1^{\mathrm{b}}$ & $1.07 \mathrm{Ba}$ & $1.86 \mathrm{Ab}$ & $1.27 \mathrm{Ba}$ & $2.75 \mathrm{Aa}$ & 0.0898 & $<0.0001$ & $<0.0001$ & 0.0095 \\
\hline cis-9 C18:1 & 16.01 & 11.89 & 15.72 & 11.94 & 0.6207 & 0.8146 & $<0.0001$ & 0.7623 \\
\hline cis-9, cis-12 C18:2 & $18.09 \mathrm{Ba}$ & $20.93 \mathrm{Ab}$ & $18.21 \mathrm{Ba}$ & $23.65 \mathrm{Aa}$ & 0.6271 & 0.0310 & $<0.0001$ & 0.0463 \\
\hline$c-9, c-12, c-15 \mathrm{C} 18: 3$ & 1.54 & 1.50 & 1.71 & 1.54 & 0.0686 & 0.1408 & 0.1397 & 0.3294 \\
\hline cis-9, trans-11 CLA & 0.14 & 0.17 & 0.15 & 0.19 & 0.0087 & 0.2181 & 0.0008 & 0.5183 \\
\hline trans-10, cis-12 CLA & 0.030 & 0.029 & 0.038 & 0.019 & 0.0047 & 0.8680 & 0.0355 & 0.0743 \\
\hline $\mathrm{C} 20: 5 \mathrm{EPA}(\omega-3)^{\mathrm{c}}$ & 0.45 & 0.45 & 0.38 & 0.44 & 0.0353 & 0.2325 & 0.4424 & 0.3908 \\
\hline anteiso $\mathrm{C} 15: 0$ & 0.52 & 0.51 & 0.40 & 0.46 & 0.0279 & 0.0045 & 0.3050 & 0.2307 \\
\hline $\mathrm{C} 15: 0$ & 0.48 & 0.46 & 0.44 & 0.45 & 0.0119 & 0.0369 & 0.5713 & 0.2226 \\
\hline anteiso C17:0 & 0.39 & 0.36 & 0.36 & 0.32 & 0.0341 & 0.3306 & 0.3763 & 0.8547 \\
\hline $\mathrm{C} 17: 0$ & 0.53 & 0.52 & 0.50 & 0.49 & 0.0111 & 0.0067 & 0.4122 & 0.7325 \\
\hline
\end{tabular}

${ }^{a} \mathrm{NEFA}=$ nonesterified FA; ${ }^{b}$ Means followed by the same letters, uppercase in the comparison between oil types in each method of concentrate feeding and lowercase in the comparison between the methods of concentrate feeding for each oil type, do not differ at 5\% probability; ${ }^{c}$ Eicosapentaenoic acid (cis-5, cis-8, cis-11, cis-14, cis-17 C20:5).

Concerning the method of concentrate feeding, higher milk fat contents of palmitic and stearic acids, anteiso $\mathrm{C} 15: 0, \mathrm{C} 15: 0$, anteiso $\mathrm{C} 17: 0$ (Table 8) and trans-10 C18:1 (Table 9) were observed in TMR- fed cows ( $\mathrm{P}<0.05)$, while higher milk fat contents of vaccenic acid (Table 9), rumenic acid and trans-9, cis-11 CLA (Table 10) were observed in cows that received concentrate twice a day $(\mathrm{P}<0.01)$. 
Table 8

Major linear even-chain saturated fatty acids and major odd- and branched-chain fatty acids (OBCFAs) in the milk fat of cows fed chopped elephantgrass-based diets containing two types of sunflower oil (high versus medium oleic acid content) associated with two methods of concentrate feeding (TMR versus twice a day after the morning and afternoon milkings)

\begin{tabular}{|c|c|c|c|c|c|c|c|c|}
\hline \multirow{2}{*}{$\begin{array}{l}\text { Fatty acid (FA) } \\
\left(\text { g } 100 \mathrm{~g}^{-1} \mathrm{FA}\right)\end{array}$} & \multicolumn{2}{|c|}{ TMR } & \multicolumn{2}{|c|}{ Twice a day } & \multirow[b]{2}{*}{ SEM } & \multicolumn{3}{|c|}{ P-value } \\
\hline & $\begin{array}{l}\text { High } \\
\text { oleic }\end{array}$ & $\begin{array}{c}\text { Medium } \\
\text { oleic }\end{array}$ & $\begin{array}{l}\text { High } \\
\text { oleic }\end{array}$ & $\begin{array}{c}\text { Medium } \\
\text { oleic }\end{array}$ & & $\begin{array}{l}\text { Method } \\
\text { (M) }\end{array}$ & $\begin{array}{l}\text { Oil } \\
(\mathrm{O})\end{array}$ & $\mathrm{M}^{*} \mathrm{O}$ \\
\hline$\Sigma 4 \leq \mathrm{C} \leq 10$ & 5.44 & 4.98 & 5.65 & 5.73 & 0.2158 & 0.0325 & 0.3898 & 0.2214 \\
\hline $\mathrm{C} 12: 0$ & 1.44 & 1.24 & 1.50 & 1.30 & 0.0605 & 0.3350 & 0.0027 & 0.9853 \\
\hline C14:0 & 6.91 & 6.25 & 7.15 & 6.27 & 0.1935 & 0.4931 & 0.0004 & 0.5793 \\
\hline C16:0 & 19.66 & 21.81 & 18.76 & 20.89 & 0.4311 & 0.0422 & $<0.0001$ & 0.9859 \\
\hline C18:0 & 16.28 & 14.25 & 14.80 & 13.04 & 0.6145 & 0.0365 & 0.0043 & 0.8296 \\
\hline$\Sigma 18 \leq \mathrm{C} \leq 24$ & 16.51 & 14.45 & 15.01 & 13.23 & 0.6216 & 0.0364 & 0.0042 & 0.8215 \\
\hline iso $\mathrm{C} 15: 0$ & 0.23 & 0.21 & 0.22 & 0.20 & 0.0082 & 0.3049 & 0.0133 & 0.6270 \\
\hline anteiso $\mathrm{C} 15: 0$ & 0.43 & 0.41 & 0.37 & 0.37 & 0.0107 & $<0.0001$ & 0.6726 & 0.4227 \\
\hline $\mathrm{C} 15: 0$ & 0.91 & 0.91 & 0.80 & 0.79 & 0.0162 & $<0.0001$ & 0.7481 & 0.6743 \\
\hline anteiso $\mathrm{C} 17: 0$ & 0.45 & 0.42 & 0.40 & 0.36 & 0.0118 & $<0.0001$ & 0.0166 & 0.6508 \\
\hline $\mathrm{C} 17: 0$ & 0.29 & 0.26 & 0.26 & 0.26 & 0.0124 & 0.2922 & 0.3443 & 0.3494 \\
\hline
\end{tabular}

Table 9

cis- and trans-monounsaturated fatty acids in the milk fat of cows fed chopped elephantgrass-based diets containing two types of sunflower oil (high versus medium oleic acid content) associated with two methods of concentrate feeding (TMR versus twice a day after the morning and afternoon milkings)

\begin{tabular}{|c|c|c|c|c|c|c|c|c|}
\hline \multirow{2}{*}{$\begin{array}{l}\text { Fatty acid (FA) } \\
\left(\mathrm{g} 100 \mathrm{~g}^{-1} \mathrm{FA}\right)\end{array}$} & \multicolumn{2}{|c|}{ TMR } & \multicolumn{2}{|c|}{ Twice a day } & \multirow[b]{2}{*}{ SEM } & \multicolumn{3}{|c|}{ P-value } \\
\hline & $\begin{array}{l}\text { High } \\
\text { oleic }\end{array}$ & $\begin{array}{c}\text { Medium } \\
\text { oleic }\end{array}$ & $\begin{array}{l}\text { High } \\
\text { oleic }\end{array}$ & $\begin{array}{c}\text { Medium } \\
\text { oleic }\end{array}$ & & $\begin{array}{l}\text { Method } \\
\text { (M) }\end{array}$ & $\begin{array}{l}\text { Oil } \\
(\mathrm{O})\end{array}$ & $\mathrm{M} * \mathrm{O}$ \\
\hline cis-9 C14:1 & 0.42 & 0.54 & 0.52 & 0.53 & 0.0366 & 0.2617 & 0.0996 & 0.1029 \\
\hline cis-9 C16:1 & 0.81 & 0.97 & 0.78 & 0.92 & 0.0456 & 0.3849 & 0.0023 & 0.9426 \\
\hline cis-9 C18:1 & 28.65 & 26.83 & 29.10 & 25.21 & 0.5292 & 0.2751 & $<0.0001$ & 0.0600 \\
\hline cis-11 C18:1 & 1.13 & 1.08 & 1.15 & 1.08 & 0.0442 & 0.9068 & 0.1787 & 0.8499 \\
\hline cis-12 C18: $1^{\mathrm{a}}$ & $0.26 \mathrm{Ba}$ & $0.40 \mathrm{Aa}$ & $0.22 \mathrm{Aa}$ & $0.26 \mathrm{Ab}$ & 0.0149 & $<0.0001$ & $<0.0001$ & 0.0008 \\
\hline cis-13 C18:1 & 0.14 & 0.12 & 0.14 & 0.10 & 0.0065 & 0.2837 & $<0.0001$ & 0.2020 \\
\hline trans-4 C18:1 & 0.13 & 0.08 & 0.14 & 0.08 & 0.0052 & 0.2282 & $<0.0001$ & 0.2528 \\
\hline trans-5 C18:1 & 0.12 & 0.07 & 0.13 & 0.07 & 0.0041 & 0.0962 & $<0.0001$ & 0.3304 \\
\hline trans-6-8 C18:1 & $1.13 \mathrm{Ab}$ & $0.84 \mathrm{Ba}$ & $1.24 \mathrm{Aa}$ & $0.73 \mathrm{Bb}$ & 0.0295 & 0.6557 & $<0.0001$ & 0.0006 \\
\hline trans-9 C18:1 & 1.00 & 0.79 & 0.99 & 0.72 & 0.0271 & 0.1628 & $<0.0001$ & 0.3385 \\
\hline trans-10 C18:1 & 0.82 & 0.74 & 0.73 & 0.66 & 0.0204 & 0.0002 & 0.0017 & 0.8484 \\
\hline trans-11 C18:1 & 3.38 & 5.45 & 4.48 & 7.97 & 0.1811 & $<0.0001$ & $<0.0001$ & 0.0570 \\
\hline trans-12 C18:1 & 0.76 & 0.86 & 0.73 & 0.84 & 0.0190 & 0.2030 & $<0.0001$ & 0.6149 \\
\hline trans-13-14 C18:1 & 0.74 & 0.79 & 0.74 & 0.72 & 0.0243 & 0.1412 & 0.4006 & 0.1931 \\
\hline trans-16 C18:1ª & $0.44 \mathrm{Ba}$ & $0.50 \mathrm{Aa}$ & $0.43 \mathrm{Aa}$ & $0.40 \mathrm{Ab}$ & 0.0148 & 0.0004 & 0.2206 & 0.0086 \\
\hline
\end{tabular}

${ }^{a}$ Means followed by the same letters, uppercase in the comparison between oil types in each method of concentrate feeding and lowercase in the comparison between the methods of concentrate feeding for each oil type, do not differ at $5 \%$ probability. 
Table 10

Conjugated isomers of linoleic acid (CLA), omega $6(\omega-6)$ and omega $3(\omega-3)$ fatty acids in the milk fat of cows fed chopped elephantgrass-based diets containing two types of sunflower oil (high versus medium oleic acid content) associated with two methods of concentrate feeding (TMR versus twice a day)

\begin{tabular}{|c|c|c|c|c|c|c|c|c|}
\hline \multirow{2}{*}{$\begin{array}{l}\text { Fatty acid (FA) } \\
\left(\mathrm{g} 100 \mathrm{~g}^{-1} \mathrm{FA}\right)\end{array}$} & \multicolumn{2}{|c|}{ TMR } & \multicolumn{2}{|c|}{ Twice a day } & \multirow[b]{2}{*}{ SEM } & \multicolumn{3}{|c|}{ P-value } \\
\hline & $\begin{array}{l}\text { High } \\
\text { oleic }\end{array}$ & $\begin{array}{c}\text { Medium } \\
\text { oleic }\end{array}$ & $\begin{array}{l}\text { High } \\
\text { oleic }\end{array}$ & $\begin{array}{c}\text { Medium } \\
\text { oleic }\end{array}$ & & $\begin{array}{l}\text { Method } \\
\text { (M) }\end{array}$ & $\begin{array}{l}\text { Oil } \\
(\mathrm{O})\end{array}$ & $\mathrm{M} * \mathrm{O}$ \\
\hline cis-9, trans-11 CLA & 1.30 & 2.15 & 1.81 & 3.24 & 0.0885 & $<0.0001$ & $<0.0001$ & 0.0931 \\
\hline trans-9, cis-11 CLA & 0.043 & 0.062 & 0.055 & 0.083 & 0.0041 & 0.0002 & $<0.0001$ & 0.2426 \\
\hline trans-10, cis-12 CLA & 0.019 & 0.026 & 0.019 & 0.029 & 0.0021 & 0.6012 & 0.0005 & 0.5233 \\
\hline Linoleic acid $(\omega-6)$ & 0.99 & 1.15 & 0.99 & 1.28 & 0.0405 & 0.1497 & $<0.0001$ & 0.1309 \\
\hline C18:3 GLA $(\omega-6)^{\mathrm{a}}$ & 0.023 & 0.023 & 0.026 & 0.031 & 0.0023 & 0.0185 & 0.3308 & 0.3308 \\
\hline$\alpha$-linolenic acid $(\omega-3)$ & 0.093 & 0.092 & 0.094 & 0.104 & 0.0060 & 0.2594 & 0.4976 & 0.3563 \\
\hline C20:2 EA $(\omega-6)^{\mathrm{b}}$ & 0.013 & 0.013 & 0.013 & 0.015 & 0.0008 & 0.2528 & 0.0611 & 0.1499 \\
\hline C20:3 DGLA $(\omega-6)^{\mathfrak{c}}$ & 0.033 & 0.036 & 0.033 & 0.032 & 0.0020 & 0.4493 & 0.7042 & 0.3147 \\
\hline C20:4 ARA $(\omega-6)^{\mathrm{d}}$ & 0.061 & 0.058 & 0.061 & 0.067 & 0.0041 & 0.3356 & 0.6613 & 0.2461 \\
\hline C20:5 EPA $(\omega-3)^{e}$ & 0.047 & 0.036 & 0.046 & 0.034 & 0.0039 & 0.7428 & 0.0078 & 0.8814 \\
\hline
\end{tabular}

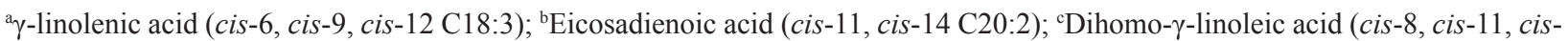

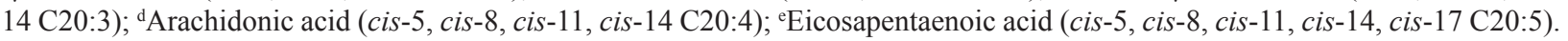

Concerning the oil type, higher $(\mathrm{P}<0.05)$ milk fat contents of lauric, myristic and stearic acids, iso C15:0, anteiso $\mathrm{C} 17: 0$ (Table 7), oleic and elaidic acids, trans-10 C18:1 (Table 9) and eicosapentaenoic acid (EPA, cis-5, cis-8, cis-11, cis14, cis-17 C20:5) (Table 10) were observed in cows that received $\mathrm{HO} \mathrm{SO}$, while higher $(\mathrm{P}<0.05)$ milk fat contents of palmitic (Table 8), vaccenic (Table 9), rumenic and linoleic acids, trans-10, cis-12 CLA and trans-9, cis-11 CLA (Table 10) were observed in cows that received MO SO.

\section{Discussion}

The usual explanation for the increase in DM intake of cows receiving TMRs is associated with an effect of more steady daily distributions of concentrate intake over a 24-hour period. In theory, this reduces any fluctuations that may occur within the rumen environment throughout the day, allowing stability in fermentation patterns, constancy in rumen digestion of the fibrous fraction of the diet and therefore increased consumption (Phipps, Bines, Fulford, \& Weller, 1984). The results in Experiment 1 indicate that in both methods of concentrate feeding, the rumen environment of cows over a 24-hour period can be considered stable and adequate for fibrous carbohydrate fermentation, with $\mathrm{pH}$ values that are always above 6.0 (Figure 1) and $\mathrm{N}-\mathrm{NH}_{3}$ contents that are always above $10 \mathrm{mg} \mathrm{dL}^{-1}$ (data not shown) (Valadares \& Pina, 2011). This partly explains the observed similarity between the methods of concentrate feeding in NDF degradability parameters (Table 4) but does not explain the higher DM intakes and ruminal passage rates in cows receiving TMRs (Table 5). In turn, in response to the higher rumen passage rates and $\mathrm{DM}$, $\mathrm{CP}, \mathrm{NDF}_{\text {ap }}$ and $\mathrm{NFC}_{\text {ap }}$ intakes (Table 5), there was more fermentable substrate available in the rumen of TMR-fed cows, which accounted for the $18 \%, 16 \%$, $18 \%$ and $15 \%$ increments in the rumen contents of $\mathrm{N}_{-} \mathrm{NH}_{3}$, acetate, propionate and total VFAs, respectively. In turn, the $2 \%$ reduction in the mean ruminal $\mathrm{pH}$ value of TMR-fed cows (6.33 versus 
6.48; Table 4) is a consequence of the increase in the rumen content of total VFAs (Figure 1), justified by the negative correlation between these ruminal parameters $\left(\mathrm{r}_{\mathrm{pH} \text { vs. VFA }}=-0.83 ; \mathrm{P}<0.0001\right)$.

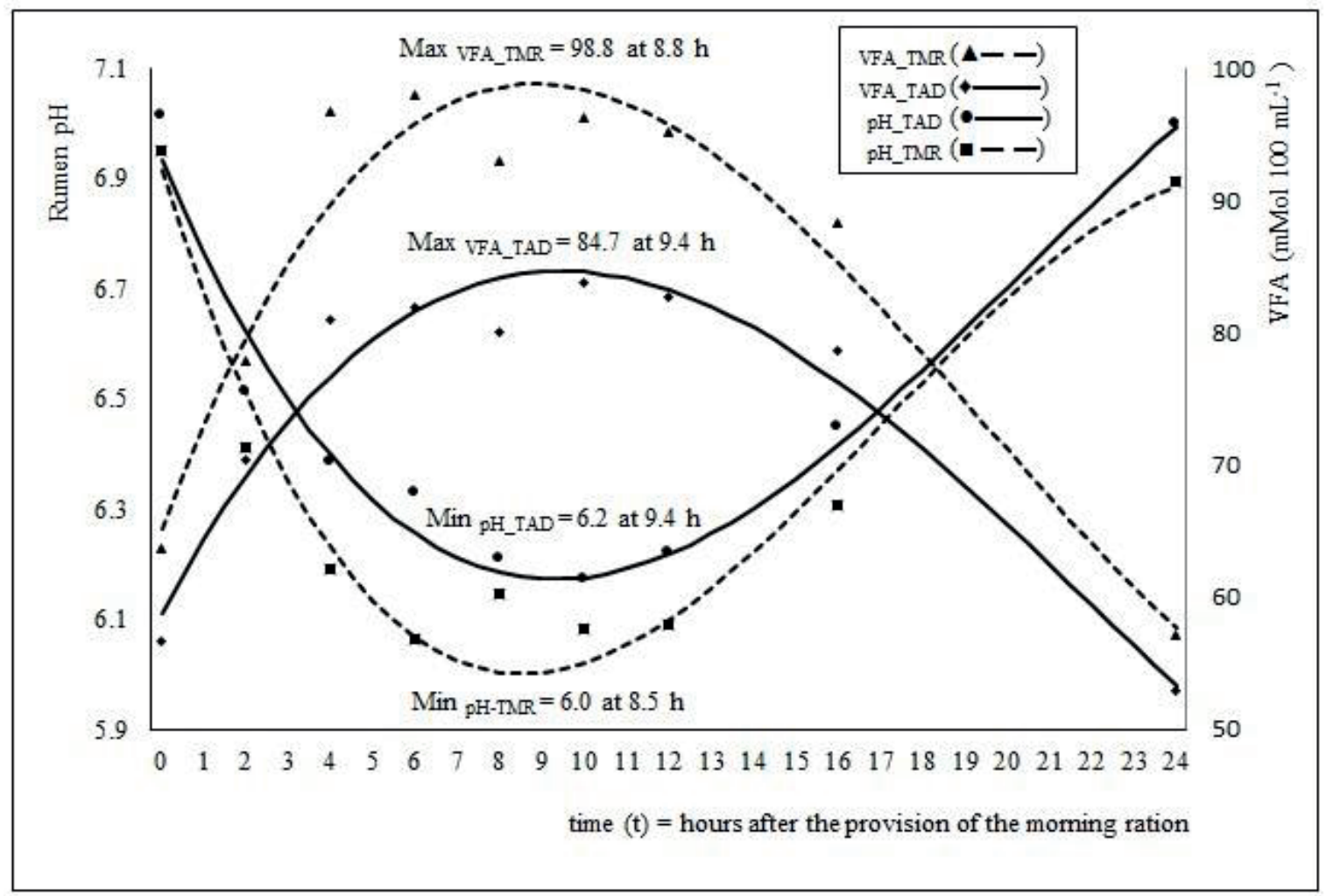

Figure 1. Effect of sampling time (t, hour) on the $\mathrm{pH}$ and total volatile fatty acid (VFA) concentration in the rumen of cows fed chopped elephantgrass-based diets supplemented with concentrate containing sunflower oil, supplied separately from the forage twice a day (TAD) or as part of a total mixed ration (TMR).

Thus, it is likely that the explanation for the higher nutrient intake and rate passage of solids in the rumen of TMR-fed cows (Table 5) is associated with the rumen $\mathrm{BH}$ processes resulting from monounsaturated FA (MUFA) and PUFA intakes, which varied according to the factors studied (Table 5).

According to Harvatine and Allen (2004), the rumen $\mathrm{BH}$ is determined by the pool size of available FA, rumen retention time, and bacterial hydrogenation capacity, which is a function of the bacterial population and rumen environment. The TMR-fed cows consumed, on average, 272, 159 and $29 \mathrm{~g} \mathrm{day}^{-1}$ of oleic, linoleic and $\alpha$-linolenic acids, respectively, distributed over a 24-hour period. On the other hand, the TAD-fed cows consumed, on average, 246, 142 and $26 \mathrm{~g}^{\text {day }}{ }^{-1}$ of oleic, linoleic and $\alpha$-linolenic acids, respectively, divided into two meals (Table 5). That is, the high MUFA and PUFA load that reached the rumen of the TAD-fed cows at each time of concentrate supply (i.e., $\sim 123,71$ and $13 \mathrm{~g}$ of oleic, linoleic and $\alpha$-linolenic acids, respectively) may have compromised the resident microbiota's BH capacity, as well as causing intense microbial population dysbiosis. On the other hand, in the TMR-fed cows, the unsaturated FA load that reached the rumen was supposedly better distributed over a 24-hour period, not exceeding the hydrogenating capacity and preventing potential deleterious effects on the resident microbiota. This hypothesis is supported by the higher stearic acid 
content in the milk fat of TMR-fed cows (Table 8 ), partially indicating greater $\mathrm{BH}$ extension in the rumen, since part of the stearic acid secreted in milk fat originates from adipose tissue mobilization $\left(\mathrm{r}_{\text {NEFA versus milk fat } \mathrm{C} 18: 0 \text { content }}=0.40 ; \mathrm{P}=0.0278\right.$ ) (He et al., 2012; Prado, Schmidely, Nozière, \& Ferlay, 2019). In addition, the contents of various OBCFAs in plasma (anteiso C15:0, C15:0, C17:0; Table 7) and milk fat (e.g., anteiso C15:0, C15:0, anteiso C17:0; Table 8) of TMR-fed cows were higher than those in TAD-fed cows. OBCFAs have been used as indirect noninvasive markers of rumen function (Renna et al., 2014; Zhang, Liu, Hao, \& Xin, 2017); they originate from the digestion and absorption of lipids synthesized by ruminal bacteria, as well as from de novo FA synthesis in the mammary gland (Prado et al., 2019). This finding indicates that the high unsaturated FAs reaching the rumen of the TAD-fed cows at both times of concentrate supply promoted changes in the ruminal environment and microbial population, possibly impairing the development of certain species and communities of bacteria more vulnerable to the toxic effects of unsaturated FAs. These changes may have slowed down the rumen fermentation process and synergistically contributed to the observed reduction in rate passage of solids in the rumen of TAD-fed cows (Table 5).

The higher plasma OBCFA contents in TMRfed cows (Table 8) are associated with ruminal carbohydrate and $\mathrm{N}$ metabolism. In the rumen of the TMR-fed cows, there was greater availability of propionate to be used as primer (propionyl-CoA) and acetate (Table 4) for odd-chain FA elongation (Prado et al., 2019). In synchronism with this, the higher CP intake by TMR-fed cows (Table 5) promoted greater availability of ruminal $\mathrm{N}_{-} \mathrm{NH}_{3}$ (Table 4) to be used for the growth and development of rumen bacteria in these cows, which apparently happened due to the similarity in plasma urea $\mathrm{N}$ content between the methods of concentrate feeding (Table 7). In addition to the bacterial-derived OBCFAs available for plasma uptake, it is possible that from the higher rumen contents of propionate and acetate
(Table 4), there may be higher plasma contents of propionyl-CoA and acetyl-CoA, allowing increases in de novo OBCFA synthesis in the mammary gland and increasing the contents of these FAs in the milk fat of TMR-fed cows (Table 8). In line with this result, positive correlations $(\mathrm{P}<0.05)$ between the plasma and milk fat contents of OBCFA were observed (e.g., $\mathrm{r}_{\mathrm{C} 15: 0}=0.36, \mathrm{r}_{\text {anteis } \mathrm{C} 15: 0}=0.37$ ). This finding indicates that the milk yield of these FAs was partly ruminal in origin and partly arose from de novo mammary synthesis (Prado et al., 2019).

In addition to the differences in stearic acid and OBCFA milk fat contents, there were higher plasma contents of vaccenic and linoleic acids in TAD-fed cows that received MO SO (Table 7). This likely occurred in response to the high linoleic acid load that reached the rumen of these cows at each time of concentrate supply, promoting intense $\mathrm{BH}$ via the classical trans-11 pathway (Shingfield et al., 2010) as well as linoleic acid escape from the rumen. For the same reason, increases of $41 \%$ and $47 \%$ in the milk fat contents of vaccenic and rumenic acids were observed in TAD-fed cows. Additionally, the TADfed cows produced milk fat with $4 \%$ less palmitic acid, which is considered hypercholesterolemic, and 12\% less trans-10 C18:1, which together with elaidic acid is associated with deleterious effects on cardiovascular health (Vahmani, Meadus, Duff, Rolland, \& Dugan, 2017). All these changes in the milk FA composition of TAD-fed cows are desirable and beneficial to human health.

To the best of our knowledge, only in the studies by Agnew et al. (1996) and Renna et al. (2014) was the effect of the method of concentrate feeding (separately from forage or as a TMR) on the milk FA composition of cows evaluated. Contrasting the results obtained in the present trial, in both studies, there was no effect on the overall milk FA composition. However, it is likely that the frequent administration of concentrate (six times a day) applied in the study of Renna et al. (2014) reduced the unsaturated FA load that reached the rumen of these cows at each time of concentrated 
supply, minimizing its negative impact on ruminal microbiota and $\mathrm{BH}$.

Despite all differences in nutrient intake (Table 5) and ruminal fermentation parameters (Table 4), there was no effect of the method of concentrate feeding on milk yield and milk fat, protein and lactose contents and yields (Table 6). In studies with medium-yielding cows $\left(\leq 20 \mathrm{~kg} \mathrm{day}^{-1}\right)$, as in the present trial, the DM intake of TMR-fed cows was similar (Renna et al., 2014) or higher (Agnew et al., 1996) than those who received concentrate separately from forages. Corroborating our results, in these studies, there was also no effect of the method of concentrate feeding on the milk yield and milk contents of fat, protein and lactose.

There was no effect of oil type on the milk yield and milk fat and protein contents and yields (Table 6) despite the higher intakes of CP, $\mathrm{NFC}_{\text {ap }}$ $\left(\mathrm{kg} \mathrm{day}^{-1}\right), \mathrm{DM}$ and $\mathrm{NDF}_{\text {ap }}\left(\mathrm{kg} 100 \mathrm{~kg}^{-1}\right.$ of body weight) observed in cows receiving $\mathrm{HO} \mathrm{SO}$ in comparison to those fed with MO SO (Table 5). However, in the MO SO diets, the cows receiving concentrate twice a day produced milk with a higher lactose content than those fed with TMR diets (Table 6), but the similar results of rumen propionate (Table 4) and plasma glucose (Table 7) concentrations do not support this difference. Corroborating the results of the present study, other authors also did not find any effect of feeding diets rich in linoleic acid in comparison with those rich in oleic acid on the milk yield (He et al., 2012; J. C. Lopes et al., 2017; Weld \& Armentano, 2018) and milk protein and lactose contents and yields ( $\mathrm{He}$ et al., 2012; Weld \& Armentano, 2018). However, contrasting the results obtained in the present study (Table 6), feeding diets rich in linoleic acid resulted in a lower milk fat content (He et al., 2012; J. C. Lopes et al., 2017; Weld \& Armentano, 2018) and yield (Weld \& Armentano, 2018) than those rich in oleic acid. Studies have shown that dietary linoleic acid is more potent than dietary oleic acid at causing MFD (He et al., 2012; Dorea \& Armentano, 2017). In the present study, regardless of the method of concentrate feeding and oil type, the inclusion of $45 \mathrm{~g} \mathrm{~kg}^{-1} \mathrm{SO}$ did not cause MFD, and the milk fat content (Table 6) was always higher than the 3.0\% established as standard by the Brazilian legislation (Normative Instruction 76) for the composition of raw milk (Instrução Normativa $n^{\circ} 76,2018$ ). In line with this result, the correlations between the milk fat content versus milk fat or plasma contents of trans-10, cis-12 CLA, trans-9, cis-11 CLA and trans-10 C18:1, which promotes MFD (Shingfield et al., 2010; Prado et al., 2019), were not significant $(\mathrm{P}>0.05)$ for each method of concentrate feeding or oil type. However, the milk protein content was always less than $2.9 \%$ (Table 6), which is the minimum value established by Normative Instruction 76. Meta-analysis studies have shown that supplementing the diets of lactating cows with unsaturated FAs (Rabiee et al., 2012; Mahdavi, Mahdavi, Darabighane, Mead, \& Lee, 2019) promotes a reduction in milk protein content, likely a result of depressed microbial protein synthesis in the rumen (J. C. Lopes et al., 2017).

Depending on the SO type and, consequently, the mostly consumed unsaturated FAs and the associated ruminal $\mathrm{BH}$ pathways, there were differences in the plasma and milk FA profiles. In HO SO diets, there was a higher intake of the MUFA oleic acid, while in MO SO diets, the PUFA linoleic and $\alpha$-linolenic acid intakes were higher (Table 5). This difference in the degree of unsaturation of diets with HO SO and MO SO influenced the passage rate in the rumen (Table 5). The most intense PUFA bacteriostatic effect may have impaired the development of certain species and communities of bacteria, slowing down the fermentation process in the rumen of MO SO-fed cows and reducing the rate of passage. This hypothesis is supported by the higher milk fat stearic acid content in HO SOfed cows (Table 8), partially indicating greater $\mathrm{BH}$ extension of the unsaturated C18 FAs.

In response to a higher oleic acid intake (Table 5), higher contents of this FA were observed in the plasma (Table 7) and milk fat (Table 8) of HO SO- 
fed cows. Similarly, a higher linoleic acid intake (Table 5) promoted increases in the plasma and milk fat linoleic acid content in MO SO TAD-fed cows (Tables 7 and 8). In addition to the higher oleic acid content $(+11 \%)$, the milk fat of HO SO-fed cows showed other nutritionally desirable characteristics for human health due to its association with reducing the risk of cardiovascular disease, such as the lower milk fat palmitic acid content $(-10 \%)$, which is considered hypercholesterolemic, and the higher EPA content $(+34 \%)$, whose increase in consumption modified a number of risk factors for cardiovascular disease in a beneficial way (Calder, 2018). However, in the milk fat of $\mathrm{HO} \mathrm{SO}-$ fed cows, there were concomitant $32 \%$ and $10 \%$ increases in the contents of elaidic acid and trans-10 C18:1, respectively.

The milk fat of MO SO-fed cows also presented nutritionally desirable characteristics for human health, such as lower contents of the hypercholesterolemic lauric $(-14 \%)$ and myristic $(-11 \%)$ acids and $74 \%$ and $71 \%$ increases in the contents of rumenic and vaccenic acids. Anticarcinogenic, antidiabetogenic (type 2 diabetes), antiatherogenic and immunomodulatory properties have been attributed to rumenic acid (Yang et al., 2015). The plasma of cows receiving MO SO also presented higher concentrations of vaccenic and rumenic acids (Table 7). As there was no effect of oil type on the stearoyl-CoA delta-9 desaturase activity for the rumenic/vaccenic FA pair (data not shown), the higher content of plasma rumenic acid contributed to its secretion in milk fat, as shown by the regression between milk fat rumenic acid content (y; g $100 \mathrm{~g}^{-1} \mathrm{FA}$ ) versus plasma rumenic acid content (x; g $\left.100 \mathrm{~g}^{-1} \mathrm{FA}\right)$, i.e., $\hat{\mathrm{y}}=12.61137 \mathrm{x}+$ $0.08577\left(\mathrm{r}_{\text {adj }}^{2}=0.23 ; \mathrm{P}=0.0035\right)$. Diets that promote an increase in the supply of vaccenic acid from the plasma to the mammary gland generally lead to higher rumenic acid levels in milk; vaccenic acid is the precursor for the synthesis of $70-95 \%$ of the rumenic acid in bovine milk (Kliem \& Shingfield, 2016). This potential is corroborated by the positive relationship $\left(\hat{y}=1.00729 x+0.37367 ; r^{2}{ }_{a d j}=0.87\right.$;
$\mathrm{P}<0.0001$ ) between milk fat rumenic acid content (y; g $100 \mathrm{~g}^{-1}$ FA) versus plasma vaccenic acid content ( $\mathrm{x}$; g $100 \mathrm{~g}^{-1} \mathrm{FA}$ ). The vaccenic and rumenic acid contents obtained in milk fat of MO SO TADfed cows can be considered high compared to those obtained by Ribeiro et al. (2014) in a study with cows receiving chopped elephantgrass-based diet with $37 \mathrm{~g} \mathrm{~kg}^{-1} \mathrm{SO}$ on DM basis (5.727 and $2.128 \mathrm{~g}$ $100 \mathrm{~g}^{-1} \mathrm{FA}$, respectively).

The milk fat of MO SO-fed cows presented higher levels of trans-10, cis-12 CLA and trans-9, cis-11 CLA (Table 8), which are intermediates of rumen linoleic acid $\mathrm{BH}$ reactions (Shingfield et al., 2010; Buccioni et al., 2012). These CLAs and trans-10 C18:1 are associated with MFD and a reduction in de novo FA synthesis in the mammary gland (Shingfield et al., 2010; Bernard et al., 2018). Thus, despite the effects of oil type on the plasma and milk fat contents of trans-10, cis-12 CLA, trans-9, cis-11 CLA and trans-10 C18:1, it is possible that the contents of these FAs are not high enough to cause MFD. In line with this hypothesis, all correlations between the plasma and milk fat contents of trans-10, cis-12 CLA, trans-9, cis-11 CLA and trans-10 C18:1 versus milk fat content and the de novo-synthesized FAs lauric, myristic and palmitic were not significant $(\mathrm{P}>0.05)$ for each oil type. In addition, the reductions in lauric and myristic acid contents in the milk fat of cows receiving MO SO also cannot be explained by the rumen acetate and butyrate contents (Prado et al., 2019) because there were no effects of oil type on the rumen contents of these VFAs (Table 4).

\section{Conclusions}

Choppedelephantgrass-based diets supplemented with $45 \mathrm{~g} \mathrm{~kg}^{-1}$ sunflower oil supplied as part of a TMR promoted a higher intake of nutrients and rumen fermentation without affecting milk, fat, protein and lactose yields. However, cows fed with concentrate supplied separately from the forage showed a higher feed efficiency and produced milk 
fat with a more nutritionally desirable fatty acid composition for human health.

Dry matter intake, rumen fermentation, and the milk, fat, protein and lactose yields were similar for cows fed elephantgrass-based diets supplemented with $45 \mathrm{~g} \mathrm{~kg}^{-1}$ high or medium oleic acid sunflower oil. The most nutritionally positive characteristics for human health regarding the milk fat of high oleic acid sunflower oil-fed cows were the higher eicosapentaenoic $(+34 \%)$ and oleic acid $(+11 \%)$ contents and the lower palmitic acid content (-10\%). For the cows fed with medium oleic acid sunflower oil, higher milk fat contents of vaccenic $(+71 \%)$ and rumenic acids $(+74 \%)$ and lower trans-10 C18:1 (-10\%), elaidic (-32\%), lauric (-14\%) and myristic $(-11 \%)$ acids were the most nutritionally positive aspects. Considering the magnitudes of the differences in the levels of these fatty acids, it is concluded that the milk fat of cows fed with medium oleic acid sunflower oil showed a healthier milk fatty acid profile.

\section{Acknowledgments}

The authors gratefully acknowledge the Fundação de Amparo à Pesquisa de Minas Gerais (Fapemig), Conselho Nacional de Desenvolvimento Científico e Tecnológico (CNPq) and Embrapa Dairy Cattle for scholarships and for financial support of this study. We would also like to thank the technicians Ernando Ferreira Motta and Hernani Guilherme Barbosa Filho, who performed the analyses of fatty acid composition at the Laboratory of Chromatography of Embrapa Dairy Cattle.

\section{References}

Agnew, K. W., Mayne, C. S., \& Doherty, J. G. (1996). An examination of the effect of method and level of concentrate feeding on milk production in dairy cows offered a grass silage-based diet. Animal Science, 63(1), 21-31. doi: 10.1017/S1357729800028241

Bernard, L., Bonnet, M., Delavaud, C., Delosière, M., Ferlay, A., Fougère, H., \& Graulet, B. (2018). Milk fat globule in ruminant: major and minor compounds, nutritional regulation and differences among species. European Journal of Lipid Science and Technology, 120(5), 1700039. doi: 10.1002/ejlt.201700039

Buccioni, A., Decandia, M., Minieri, S., Molle, G., \& Cabiddu, A. (2012). Lipid metabolism in the rumen: new insights on lipolysis and biohydrogenation with an emphasis on the role of endogenous plant factors. Animal Feed Science and Technology, 174(1/2), 1-25. doi: 10.1016/j.anifeedsci.2012.02.009

Calder, P. C. (2018). Very long-chain n-3 fatty acids and human health: fact, fiction and the future. Proceedings of the Nutrition Society, 77(1), 52-72. doi: 10.1017/S0029665117003950

Detmann, E., Valadares, S. C., F ${ }^{o}$., Berchielli, T. T., Cabral, L. S., Ladeira, M. M., Souza, M. A.,... Azevedo, J. A. G. (2012). Métodos para análise de alimentos. Visconde do Rio Branco: Suprema.

Dorea, J. R. R., \& Armentano, L. E. (2017). Effects of common dietary fatty acids on milk yield and concentrations of fat and fatty acids in dairy cattle. Animal Production Science, 57(11), 2224-2236. doi: 10.1071/AN17335

Harvatine, K. J., \& Allen, M. S. (2004). Kinetic model of rumen biohydrogenation: fractional rates of fatty acid biohydrogenation and passage. Journal of Animal and Feed Sciences, 13(Suppl. 1), 87-90. doi: $10.22358 / \mathrm{jafs} / 73745 / 2004$

He, M., Perfield, K. L., Green, H. B., \& Armentano, L. E. (2012). Effect of dietary fat blend enriched in oleic or linoleic acid and monensin supplementation on dairy cattle performance, milk fatty acid profiles, and milk fat depression. Journal of Dairy Science, 95(3), 1447-1461. doi: 10.3168/jds.2011-4635

Instrução Normativa $n^{\circ}$ 76, de 26 de novembro de 2018. Diário Oficial da União n ${ }^{\circ} 230$ - Seção 1. Ministério da Agricultura, Pecuária e Abastecimento.

Kliem, K. E., \& Shingfield, K. J. (2016). Manipulation of milk fatty acid composition in lactating cows: opportunities and challenges. European Journal of Lipid Science and Technology, 118(11), 1661-1683. doi: 10.1002/ejlt.201400543

Lopes, F. C. F., Ribeiro, C. G. S., Rodriguez, N. M., Gama, M. A. S., Morenz, M. J. F., Antoniassi, R., \& Bizzo, H. R. (2019). Butter fatty acid composition as a function of soybean oil supplementation and time of milking, and performance of Holstein x Gyr cows fed with chopped elephant grass-based diets. Semina: Ciências Agrárias, 40(5), 2027-2044. doi: $10.5433 / 1679-0359.2019 \mathrm{v} 40 \mathrm{n} 5 \mathrm{p} 2027$ 
Lopes, J. C., Harper, M. T., Giallongo, F., Oh, J., Smith, L., Ortega-Perez,... Hristov, A. N. (2017). Effect of high-oleic-acid soybeans on production performance, milk fatty acid composition, and enteric methane emission in dairy cows. Journal of Dairy Science, 100(2), 1122-1135. doi: 10.3168/jds.2016-11911

Mahdavi, A., Mahdavi, A., Darabighane, B., Mead, A., \& Lee, M. R. F. (2019). Effects of soybean oil supplement to diets of lactating dairy cows, on productive performance, and milk fat acids profile: a meta-analysis. Italian Journal of Animal Science, 18(1), 809-819, doi: 10.1080/1828051X.2019.158 5211

Masood, A., Stark, K. D., \& Salem, N, Jr. (2005). A simplified and efficient method for the analysis of fatty acid methyl esters suitable for large clinical studies. Journal of Lipid Research, 46(10), 22992305, 2005. doi: 10.1194/jlr.D500022-JLR200

Mourthé, M. H. F., Lopes, F. C. F., Reis, R. B., Gama, M. A. S., Morenz, M. J. F., \& Salomão, B. M. (2019). Ruminal metabolic parameters and milk fatty acid profile of cows grazing Marandu grass supplemented with roasted soybeans. Semina: Ciências Agrárias, 40(2), 745-766. doi: 10.5433/1679-0359.2019v40n2 p745

National Research Council (2001). Nutrients requirements of dairy cattle (7nd ed.). Washington: National Academy Press.

Pereira, A. V., Morenz, M. J. F., Ledo, F. J. S., \& Ferreira, R. P. (2016). Capim elefante: versatilidades de usos na pecuária de leite. In D. Vilela, R. P. Ferreira, E. N. Fernandes, \& F. V. Juntolli (Eds.), Pecuária de leite no Brasil: cenários e avanços tecnológicos (pp. 187211). Brasília: EMBRAPA.

Phipps, R. H., Bines, J. A., Fulford, R. J., \& Weller, R. F. (1984). Complete diets for dairy cows: a comparison between complete diets and separate ingredients. The Journal of Agricultural Science, 103(1), 171180. doi: 10.1017/S0021859600043434

Prado, L. A., Schmidely, P., Nozière, P., \& Ferlay, A. (2019). Milk saturated fatty acids, odd- and branchedchain fatty acids, and isomers of C18:1, C18:2, and C18:3n-3 according to their duodenal flows in dairy cows: A meta-analysis approach. Journal of Dairy Science, 102(4), 3053-3070. doi: 10.3168/jds.201815194

Rabiee, A. R., Breinhild, K., Scott, W., Golder, H. M., Block, E., \& Lean, I. J. (2012). Effect of fat additions to diets of dairy cattle on milk production and components: A meta-analysis and meta-regression.
Journal of Dairy Science, 95(6), 3225-3247. doi: 10.3168/jds.2011-4895

Renna, M., Cornale, P., Lussiana, C., Battaglini, L. M., Turille, G., \& Mimosi, A. (2014). Milk yield, gross composition and fatty acid profile of dual-purpose Aosta Red Pied cows fed separate concentrate-forage versus total mixed ration. Animal Science Journal, 85(1), 37-45. doi: 10.1111/asj.12083

Ribeiro, C. G. S., Lopes, F. C. F., Gama, M. A. S., Morenz, M. J. F., \& Rodriguez, N. M. (2014). Desempenho produtivo e perfil de ácidos graxos do leite de vacas que receberam níveis crescentes de óleo de girassol em dietas à base de capim-elefante. Arquivo Brasileiro de Medicina Veterinária e Zootecnia, 66(5), 1513-1521. doi: 10.1590/1678-6886

Ribeiro, C. G. S., Lopes, F. C. F., Gama, M. A. S., Rodriguez, N. M., \& Morenz, M. J. F. (2018). Ruminal fermentation and degradation, kinetic flow of the digesta and milk fatty acid composition of cows fed chopped elephant grass supplemented with soybean oil. Semina: Ciências Agrárias, 39(4), 17751794. doi: 10.5433/1679-0359.2018v39n4p1775

Rico, D. E., Preston, S. H., Risser, J. M., \& Harvatine, K. J. (2015). Rapid changes in key ruminal microbial populations during the induction of and recovery from diet-induced milk fat depression in dairy cows. British Journal of Nutrition, 114(3), 358-367. doi: 10.1017/S0007114515001865

Rodrigues, J. P. P., Paula, R. M., Rennó, L. N., Fontes, M. M. S., Machado, A. F., Valadares, S. C., F ${ }^{\circ}, \ldots$ Marcondes, M. I. (2017). Short-term effects of soybean oil supplementation on performance, digestion, and metabolism in dairy cows fed sugarcane-based diets. Journal of Dairy Science, 100(6), 4435-4447. doi: 10.3168/jds.2016-11725

Schingoethe, D. J. (2017). A 100-year review: total mixed ration feeding of dairy cows. Journal of Dairy Science, 100(12), 10143-10150. doi: 10.3168/ jds.2017-12967

Shingfield, K. J., Bernard, L., Leroux, C., \& Chilliard, Y. (2010). Role of trans fatty acids in the nutritional regulation of mammary lipogenesis in ruminants. Animal, 4(7), 1140-1166. doi: 10.1017/ S17517311100 00510

Shingfield, K. J., Sæbø, A., Sæbø, P. C., Toivonen, V., \& Griinari, J. M. (2009). Effect of abomasal infusions of a mixture of octadecenoic acids on milk fat synthesis in lactating cows. Journal of Dairy Science, 92(9), 4317-4329. doi: 10.3168/jds.2008-2002 
Stoffel, C. M., Crump, P. M., \& Armentano, L. E. (2015). Effect of dietary fatty acid supplements, varying in fatty acid composition, on milk fat secretion in dairy cattle fed diets supplemented to less than $3 \%$ total fatty acids. Journal of Dairy Science, 98(1), 431442. doi: $10.3168 /$ jds.2014-8328

Vahmani, P., Meadus, W. J., Duff, P., Rolland, D. C., \& Dugan, M. E. R. (2017). Comparing the lipogenic and cholesterol genic effects of individual trans-18:1 isomers in liver cells. European Journal of Lipid Science and Technology, 119(3), 1600162. doi: 10.1002/ejlt.201600162

Valadares, S. C., Fº, \& Pina, D. S. (2011). Fermentação ruminal. In T. T. Berchielli, A. Vaz Pires, \& S. G. Oliveira (Eds.), Nutrição de ruminantes (2a ed., pp. 161-191). Jaboticabal: Funep.
Weld, K. A., \& Armentano, L. E. (2018). Feeding high oleic acid soybeans in place of conventional soybeans increases milk fat concentration. Journal of Dairy Science, 101(11), 9768-9776. doi: 10.3168/ jds.2018-14498

Yang, B., Chen, H., Stanton, C., Ross, R. P., Zhang, H., Chen, Y. Q., \& Chen, W. (2015). Review of the roles of conjugated linoleic acid in health and disease. Journal of Functional Foods, 15, 314-325. doi: 10.1016/j.jff.2015.03.050

Zhang, Y., Liu, K., Hao, X., \& Xin, H. (2017). The relationships between odd- and branched-chain fatty acids to ruminal fermentation parameters and bacterial populations with different dietary ratios of forage and concentrate. Journal of Animal Physiology and Animal Nutrition, 101(6), 11031114. doi: $10.1111 /$ jpn. 12602 
